ISSN 1112-9867

http://www.jfas.info

\title{
IDENTIFICATION OF FACTORS CONTROLLING THE QUALITY OF GROUNDWATER IN MITIDJA PLAIN (NORTH-ALGERIA) USING INDEXING METHOD AND STATISTICAL ANALYSIS
}

\author{
S. Zamiche ${ }^{1 *}$, F. Hamaidi-Chergui ${ }^{1}$, A. Demiai ${ }^{1}$, M. Belaidi ${ }^{2}$ \\ ${ }^{1}$ Laboratory of Biotechnology, Environment and Health, Department of Biology and Cellular \\ Physiology, Faculty of Sciences of Nature and Life, Blida University, Algeria \\ ${ }^{2}$ National Agency of Hydraulic Resources, Blida, Algeria
}

Received: 28 June 2017 / Accepted: 18 December 2017 / Published online: 01 January 2018

\begin{abstract}
In this paper, we describe the hydro geochemical processes in the aquifer of Mitidja (North-Algeria) using hydro chemical data, statistical analysis and Water Quality Index (WQI) to identify evidence of contamination processes. Two factors were found that explained hydro chemical evolution in the aquifer. These factors reveal the existence of an intrusion of seawater and mechanisms of nitrate contamination of groundwater. The effect of each parameter on the WQI show that the highest mean effective weight value belongs to the TDS, $\mathrm{NO}_{3}{ }^{-}$and $\mathrm{SO}_{4}{ }^{2-}$ parameters. These results indicated that natural and anthropogenic activities are responsible for the degrading of groundwater quality in the Mitidja plain.
\end{abstract}

Keywords: Aquifer of Mitidja; Hydro geochimistry; Nitrate contamination; intrusion of seawater; Algeria.

Author Correspondence, e-mail: samiramaster@hotmail.fr doi: $\underline{\text { http://dx.doi.org/10.4314/jfas.v10i1.19 }}$ 


\section{INTRODUCTION}

The Mitidja is a plain situated in northern of Algeria. It consists of aquifers that are the main source of drinking water for the whole center part of the country. Many studies of this aquifer have shown that the chemical compositions of groundwaters are the result of different components in relation to the type of geological reservoir and anthropogenic factors $[1,2,3$, 4]. Furthermore, nitrate data from recent study wells in the aquifer of Mitidja indicated that the nitrate content showed high values $[5,6]$. However, Pollution of groundwater in the study area poses a major environmental health hazard and it has started affecting the life of people as well as the Environment around them. All these need to be tackled holistically.The present work, therefore, focuses on the use of the multivariate statistics and the Water Quality Index combined with the Geographical Information System (GIS) to identify the most factors controlling groundwater quality in Mitidja plain.

\section{MATERIAL AND METHODOLOGY}

\subsection{Description of the study area}

The area of study, presented on figure 1, is a coastal plain located at the north of Algeria. It occupies a surface of $1450 \mathrm{~km}^{2}$ with an average altitude of $50 \mathrm{~m}$ that augment regularly towards the piedmont of the Atlas Blideen and the wrinkle of Sahel, giving to the plain the shape of basin. It divided into three parts: Eastern Mitidja, Central and Western Mitidja.. Administratively, it spans four wilayas, Blida, Algeria, Boumerdes and Tipaza [7]. Because of its proximity of the sea, the sector of study area is dominated by a Mediterranean climate characterized by a dry and hot summer, and a wet and cold winter with an average precipitation and temperature of about $632.3 \mathrm{~mm} / \mathrm{year}$ and $18.1{ }^{\circ} \mathrm{C}$ respectively. The topography planes and the very favorable climatic conditions make of it an excellent agricultural area of a surface of 129000 ha [8]. 


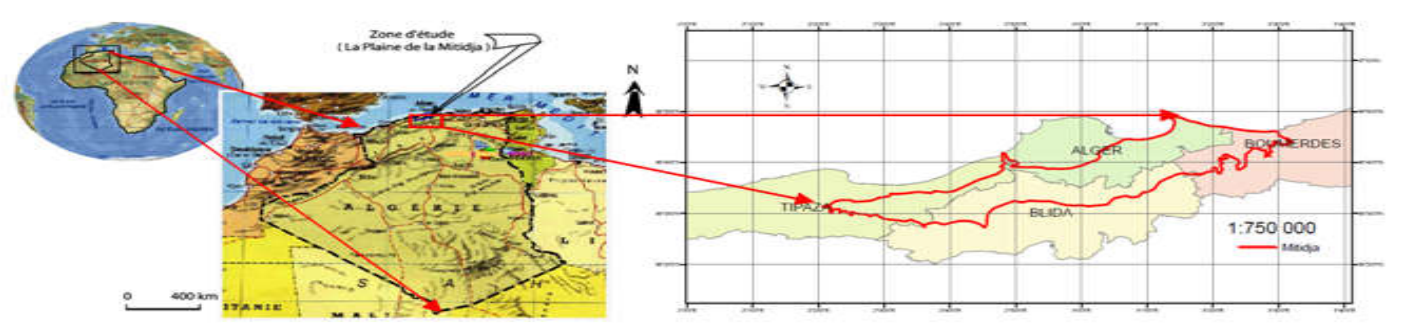

Fig.1. Map of study area [2]

\subsection{Geology and Hydrogeology}

Plain of Mitidja is a coastal alluvial basin formed by subsidence and sedimentation. It is characterized by two types of aquifers Quaternary alluvium and sandst one formation or sandstone and limestone of Astien. These two aquifers are separated by yellow marl villafranchian El-Harrach (Fig.2). The bedrock of the two aquifers is represented by marls Plaisancian[9, 10].Thus, the plain is vulnerable and mostly in some spots where the alluvial aquifer is in contact with the Astian aquifer [7]. The Quaternary alluvial aquifer of Mitidja consists mainly of gravel and pebbles alternating with silts and clays and clay, with lenses.This aquifer is to the upper surface and lowers the formation of El- Harrach. Its average thickness is 115 meters. It is fed mainly by: Precipitation, infiltration of river, tank seepage through the Astien and infiltration in the southern strip of the Sahel at the foot of the Atlas Blidéen [11].The direction of groundwater flow around Mitidja plain is from South to North. In general, the groundwater flows toward the center of the plain (Fig.2) with reduction of hydraulic gradients downstream coincides with high density of the wells in the center of the plain [4]. The pumping tests on different wells showed few transmissivity $\left(1.5 \cdot 10^{-2}\right.$ to $2.10^{-2}$ $\mathrm{m}^{2} / \mathrm{s}$ ) in comparison with the center and west part centers of aquifer and a coefficient of storage is about $3 \%$ in the West of the plain $[1,12]$. 


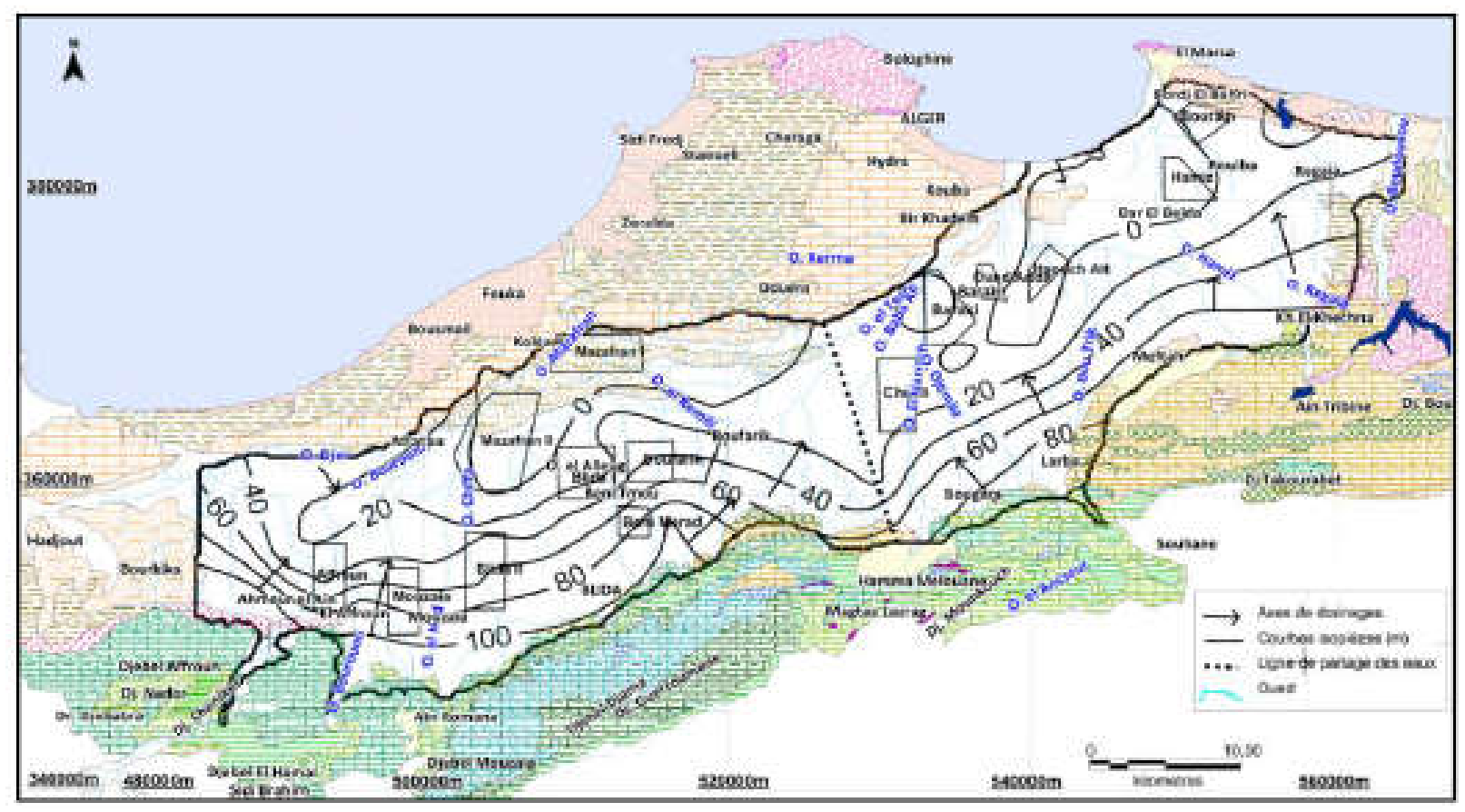

Fig.2. Potentiometric surface map in Mai, 2010 [4].

\subsection{Sample collection and analysis}

This study presents the analytical results of 30 water samples, which were collected in Juin 2015 from thirty boreholes in various parts of the basin. The hydogeochemistry of Mitidja aquifer has been studied in terms of the major ionic constituents $\mathrm{Ca}^{2+}, \mathrm{Mg}^{2+}, \mathrm{Na}^{+}, \mathrm{K}^{+}, \mathrm{Cl}^{-}$, $\mathrm{SO}_{4}{ }^{2-}, \mathrm{HCO}_{3}{ }^{-}, \mathrm{NO}_{3}{ }^{-}$and of the physical parameters ( $\mathrm{pH}$, electrical conductivity). Water samples were collected from pumping boreholes after minimum of several minutes of pumping prior to sampling. Samples were collected into 1, 5 polyethylene bottles. All the samples were stored in an ice chest at a temperature lower than $4{ }^{\circ} \mathrm{C}$ and later transferred to the laboratory. Immediately after sampling, physical parameters such as the electric conductivity (EC), water temperature $(\mathrm{T})$ and $\mathrm{pH}$ were measured in the field using a multi-parameter WTW Universal Conductivity Meter. The analytical methods are as suggested by the protocol of Rodier et al., [13]. Chemical analysis was carried out in the laboratory of the National Agency of HydraulicResources (N.A.H.R).All the results are compared with standard limits recommended by World Health Organization [14].Nitrate was analyzed by colorimetry with a UV-visible spectrophotometer. Calcium, Magnesium, Chloride and Bicarbonate were analyzed by volumetric titrations. Concentrations of Sodium and Potasium were measured using a flame photometer and that of sulfate by turbidimetric 
method. The accuracy of the chemical analyzes was checked by calculation of the ionic balance, which were generally lower than $5 \%$.

\subsection{Calculation of the Water Quality Index}

The Water Quality Index is a reliable technique to evaluate the aptitude of water for human consumption. Because, it reduces the characteristic physic-chemical of water and makes it possible to obtain small indices, easily interpretable, which reflect the chemical quality of water. Then, different techniques for the calculation of WQI's have been developed $[15,16$, 17,18]. In this study, the Water Quality index was calculated according to the indexing method suggested by Yidana and Yidana [19]. In this technique, the index is calculated starting from a table of some parameters (Tab.2). A numerical value called weight, ranging between 2 and 5, is attributed to each parameter, reflecting its degree of influence on water quality. The weights allotted to the various physicochemical parameters are presented in table 2.The relative weight (Wi) is calculated by the following equation:

$\mathrm{Wi}=\mathrm{wi} / \sum^{\mathrm{ni}=1 \mathrm{wi}}(1)$

$\mathrm{Wi}$ is the relative weight, wi is the weight of each parameter and $\mathrm{n}$ is the number of parameters. Quality rating scale of each parameter is calculated by division of the concentration of each parameter by the respective standard of WHO and multiplication by 100.

$q i=(\mathrm{Ci} / \mathrm{Si}) \times 100(2)$

$q i$ represent the quality rating, $\mathrm{Ci}$ is the concentration of each parameter in $\mathrm{mg} / \mathrm{l}$ and $\mathrm{Si}$ is the standard of the WHO of each parameter in mg/l.To calculate the WQI, SI (Sub-Index) is the first index to be determined. Then, four quality of water can be identifing according to the values of the Water Quality Index (Tab.2)

$S I i=W i \times q i(3)$

$W Q I=\sum \operatorname{SIi}(4)$ 
Table1. Relative weight of physico-chemical parameter according to WHO standards [15]

\begin{tabular}{|c|c|c|c|c|c|}
\hline \multirow[t]{2}{*}{$\begin{array}{l}\text { Chemical } \\
\text { parameters }\end{array}$} & \multirow{2}{*}{$\begin{array}{c}\text { WHO } \\
\text { Standards } \\
\text { (1984) }\end{array}$} & \multirow[t]{2}{*}{$\begin{array}{l}\text { Weightage } \\
\text { factor (wi) }\end{array}$} & \multirow[t]{2}{*}{$\begin{array}{l}\text { Relative } \\
\text { weight (Wi) }\end{array}$} & \multicolumn{2}{|c|}{$\begin{array}{l}\text { Table 2. Classification of the water } \\
\text { quality }[15,19]\end{array}$} \\
\hline & & & & Rang of & Type of water \\
\hline $\mathrm{PH}$ & $6.5-8.5$ & 4 & 0.121 & WQI & \\
\hline $\mathrm{TH}$ & 300 & 2 & 0.06 & $<50$ & Excellent water \\
\hline $\mathrm{Ca}^{+2}$ & 75 & 2 & 0.06 & $50-100.1$ & Good water \\
\hline $\mathrm{Mg}^{+2}$ & 30 & 2 & 0.06 & $100-200.1$ & Poor water \\
\hline $\mathrm{Na}^{+}$ & 200 & 2 & 0.06 & $200-300.1$ & Verypoor water \\
\hline $\mathrm{K}^{+}$ & 12 & 2 & 0.06 & $>300$ & Water unsuitable for \\
\hline TAC & 200 & 3 & 0.09 & & drinking purposes \\
\hline TDS & 500 & 4 & 0.121 & & \\
\hline $\mathrm{Cl}^{-}$ & 250 & 3 & 0.09 & & \\
\hline $\mathrm{NO}_{3-}^{-}$ & 45 & 5 & 0.15 & & \\
\hline $\mathrm{SO}_{4}^{-2}$ & 200 & 4 & 0121 & & \\
\hline & & $\sum w i=33$ & 0.994 & & \\
\hline
\end{tabular}

\section{RESULTS AND DISCUSSION}

The Table 3 gives the descriptive statistical measures of the chemical parameters investigated along with the World Health Organization standards [14].From the Table $3 \mathrm{pH}$ value ranges from 7.1 to 8.3 with an average of 7.68. According to Zghibi et al [20], PH variation in groundwater may be indicating an influence of the anthropogenic pollution of groundwater by the infiltration of domestic and industrial waste water. TDS values in groundwater vary from 301 to $1575 \mathrm{mg} / \mathrm{l}$, with a mean value of $915.93 \mathrm{mg} / \mathrm{l}$.TDS define the inorganic composition of water, and of small amounts of organic matter that are dissolved in water [21]. 
Table 3. Statistical summary of the chemical parameters of the groundwater

\begin{tabular}{|cccccc|}
\hline Parameter & WHO & Min & Max & Mean & SD \\
& $\mathbf{( 1 9 8 4 )}$ & & & & \\
$\mathbf{C a}^{2+}$ & 75 & 22 & 254 & 143.57 & 53.74 \\
$\mathbf{M g}^{2+}$ & 30 & 2 & 73 & 32.57 & 20.36 \\
$\mathbf{N a}^{+}$ & 200 & 19 & 148 & 65.20 & 40.23 \\
$\mathbf{K}^{+}$ & 12 & 2 & 8 & 2.90 & 1.37 \\
$\mathbf{C I}^{-}$ & 250 & 32 & 312 & 127.10 & 85.88 \\
$\mathbf{S O}^{2-}$ & 200 & 2 & 424 & 160.30 & 111.20 \\
$\mathbf{H C O}^{-}$ & 500 & 107 & 549 & 340.73 & 101.44 \\
$\mathbf{N O}^{-}$ & 45 & 2 & 93 & 38.47 & 26.63 \\
$\mathbf{P H}^{-}$ & $6.5-7.5$ & 7.10 & 8.30 & 7.68 & 0.29 \\
$\mathbf{E C}$ & 1500 & 520 & 2600 & 1473.17 & 604.79 \\
$\mathbf{T D S}$ & 1000 & 301 & 1575 & 915.93 & 362.70 \\
$\mathbf{T H}$ & 300 & 9 & 94 & 49.50 & 20.94 \\
$\mathbf{T A C}^{-}$ & 200 & 9 & 45 & 28.07 & 8.30 \\
$\mathbf{W Q I}^{-}$ & - & $\mathbf{3 8 . 3 6}$ & $\mathbf{1 4 2 . 4 8}$ & $\mathbf{8 5 . 1 5 3 0}$ & 31.40 \\
\hline
\end{tabular}

Salinity increases from the eastern part to south-western part of Mitidja plain along the direction of groundwater flow (Fig.4b). According to Fig. 4b, the lower TDS values $(<600$ $\mathrm{mg} / \mathrm{l}$ ) occur at the center part of the region, around the wilaya of Blida. In comparison, the entire of coastal region, especially the extreme south-west and nourth-east, are characterized by strong salinity. In these regions, the TDS values area dramatically increased, ranging in values between 1000 and $1500 \mathrm{mg} / \mathrm{l}$. Elevated concentrations of TDS in the western of Mitidja is attributed to human activities such as The rejection of domestic and industrial waste water without preliminary treatment and agricultural activities by the intensive use of waste water for irrigation. Furthermore, the increasing of TDS in oriental of Mitidja is attributed at the front of the advancing seawater.In the groundwater samples, the electrical conductivity values range from 520 to $2600 \mu \mathrm{S} / \mathrm{cm}$, with an average of $1473.17 \mu \mathrm{S} / \mathrm{cm}$. Note that the 
highest value of EC is located in western and eastern of the study area (Fig.4a).

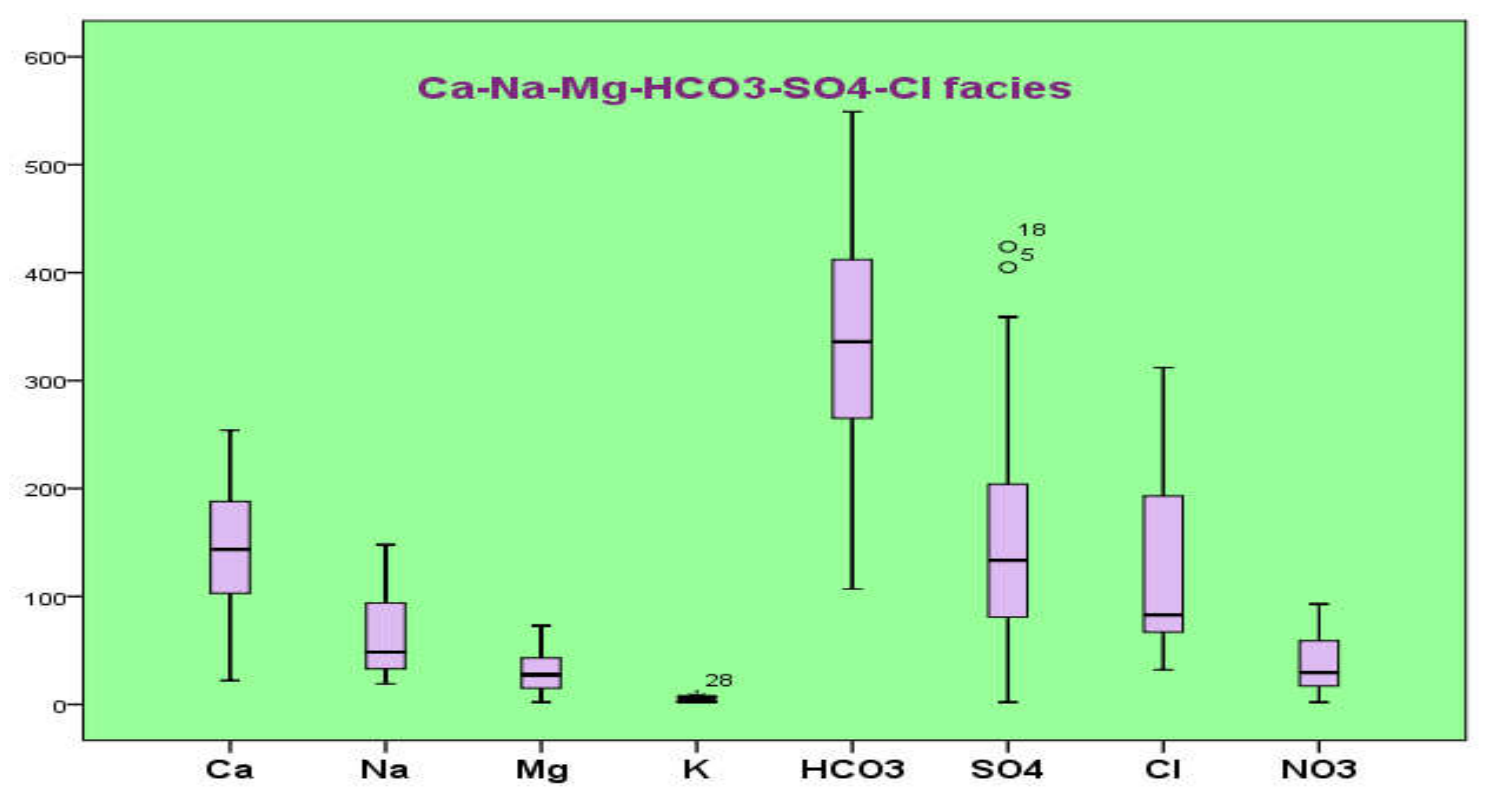

Fig.3. Box plot of major ions

As shown in Fig.3, the major cations $\mathrm{Ca}^{2+}, \mathrm{Mg}^{2+}, \mathrm{Na}^{+}, \mathrm{K}^{+}$are all low with mean concentrations of $143.57,32.57,65.20$ and $2.9 \mathrm{mg} / 1$ respectively. The major anions $\mathrm{Cl}^{-}, \mathrm{SO}_{4}{ }^{2-}$, $\mathrm{HCO}_{3}{ }^{-}$and $\mathrm{NO}_{3}{ }^{-}$are also low with mean concentrations of $127.10 \mathrm{mg} / 1,160.30 \mathrm{mg} / 1,340.73$ $\mathrm{mg} / \mathrm{l}$ and $38.47 \mathrm{mg} / \mathrm{l}$, respectively. The concentration of dissolved major cations and anions in the aquifer of Mitidja was in the order of: $\mathrm{Ca}^{2+}>\mathrm{Na}^{+}>\mathrm{Mg}^{2+}>\mathrm{K}^{+}$for cations and $\mathrm{HCO}_{3}^{-}>$ $\mathrm{SO}_{4}{ }^{2-}>\mathrm{Cl}^{-}>\mathrm{NO}_{3}{ }^{-}$for anions (Fig.3). The average concentrations of the chemical parameters indicate that the groundwater of the area is suitable for drinking in all samples except $\mathrm{Ca}^{2+}$ and $\mathrm{Mg}^{2+}$. Water Quality Index (WQI) was calculated for the samples using the concentrations of $\mathrm{pH}, \mathrm{TDS}, \mathrm{TH}, \mathrm{Ca}^{2+}, \mathrm{Mg}^{2+}, \mathrm{TAC}, \mathrm{Cl}^{-}, \mathrm{SO}_{4}^{-2}, \mathrm{Na}^{+}, \mathrm{K}^{+}$and $\mathrm{NO}_{3}{ }^{-}$at the various sample locations. The value of WQI ranged from 38.36 to 142.48 with a mean of $85.15 \pm 31.4$ (Tab. 3). Based on these results, $66.67 \%$ of the samples fall under good water for drinking uses and $33.33 \%$ shows poor water type (Tab.3).

\subsection{Application of the Geographical Information System}

To identify the factors controlling the quality of the quaternary aquifer of Mitidja, we had recourse to the geographical information system (GIS). This one enabled us to locate the zones of bad chemical quality of water (Fig.4a-4j). 

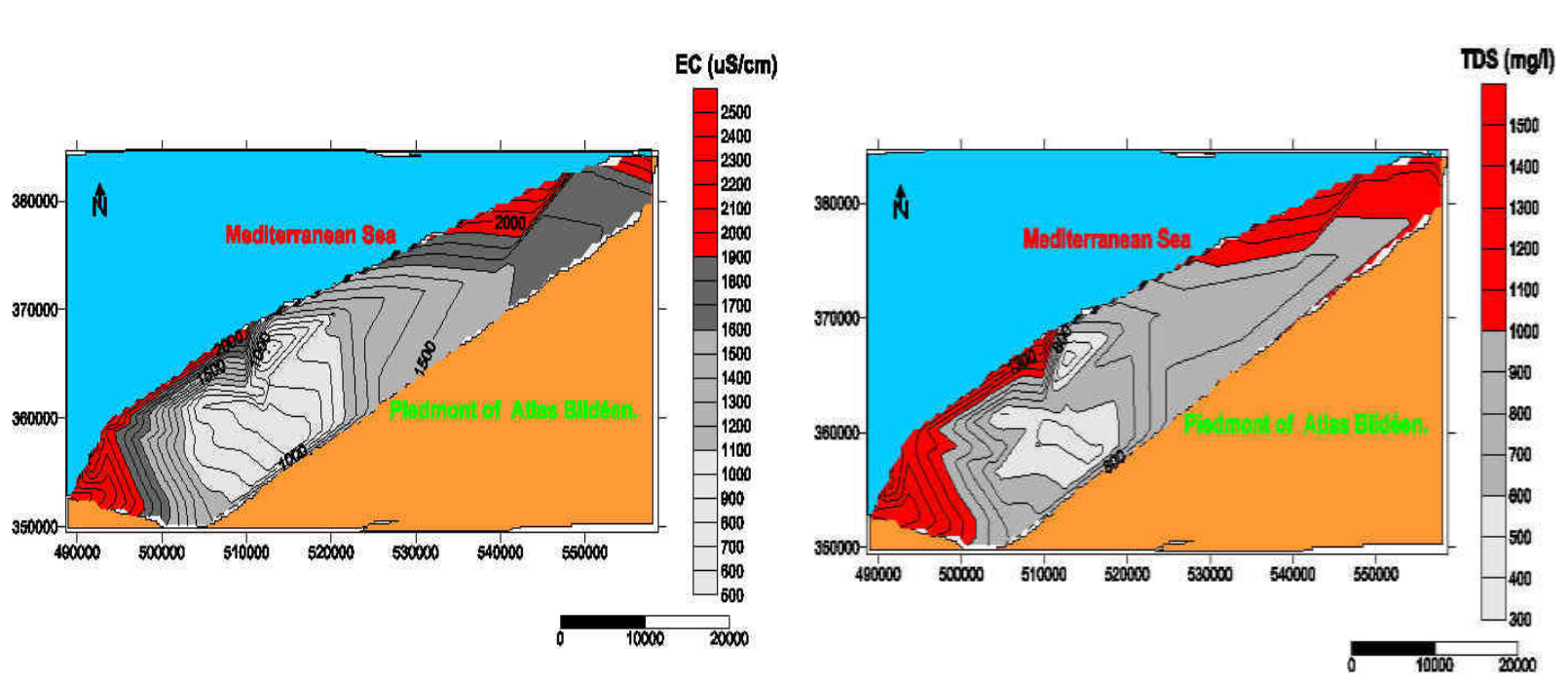

Fig.4a. Spatial distributions of EC

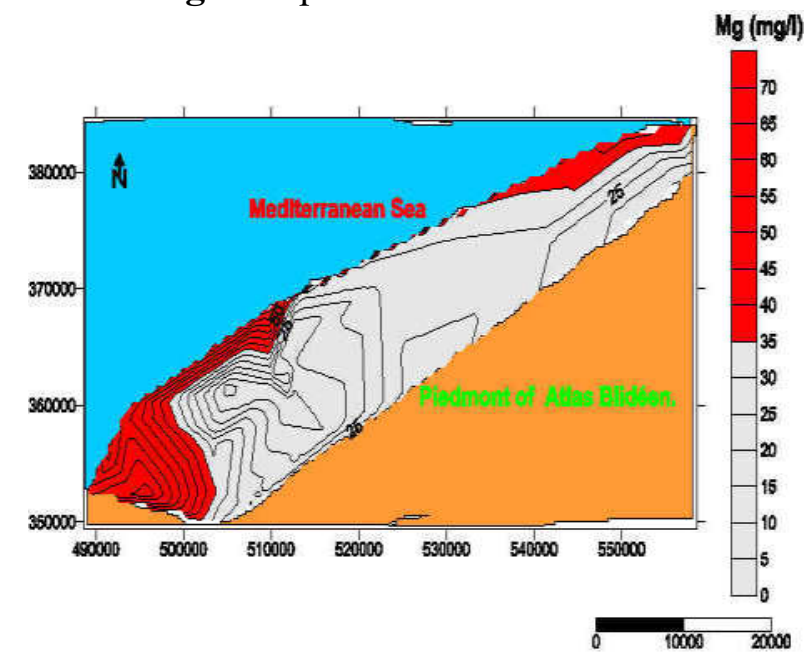

Fig.4b.Spatial distributions of TDS

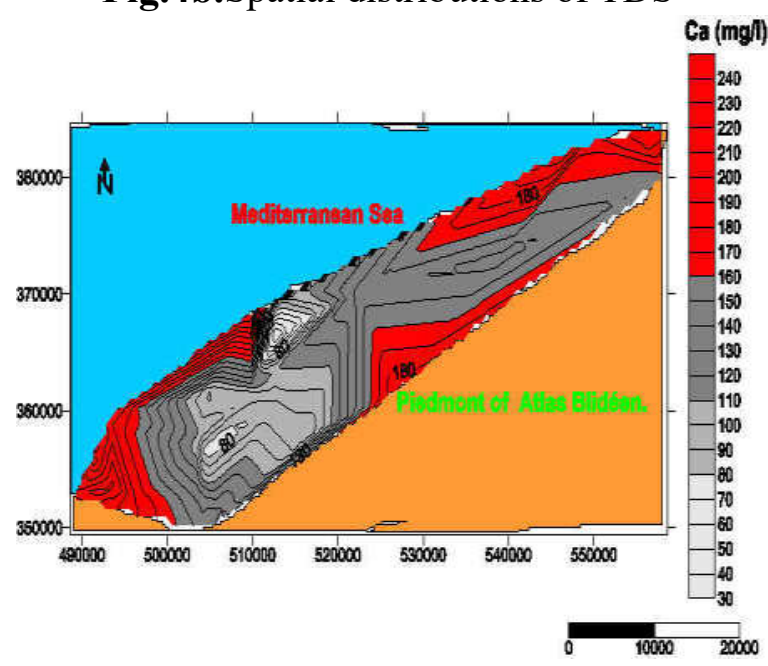

Fig.4c. Spatial distributions of Magnesium

Fig.4d. Spatial distributions of Calcium

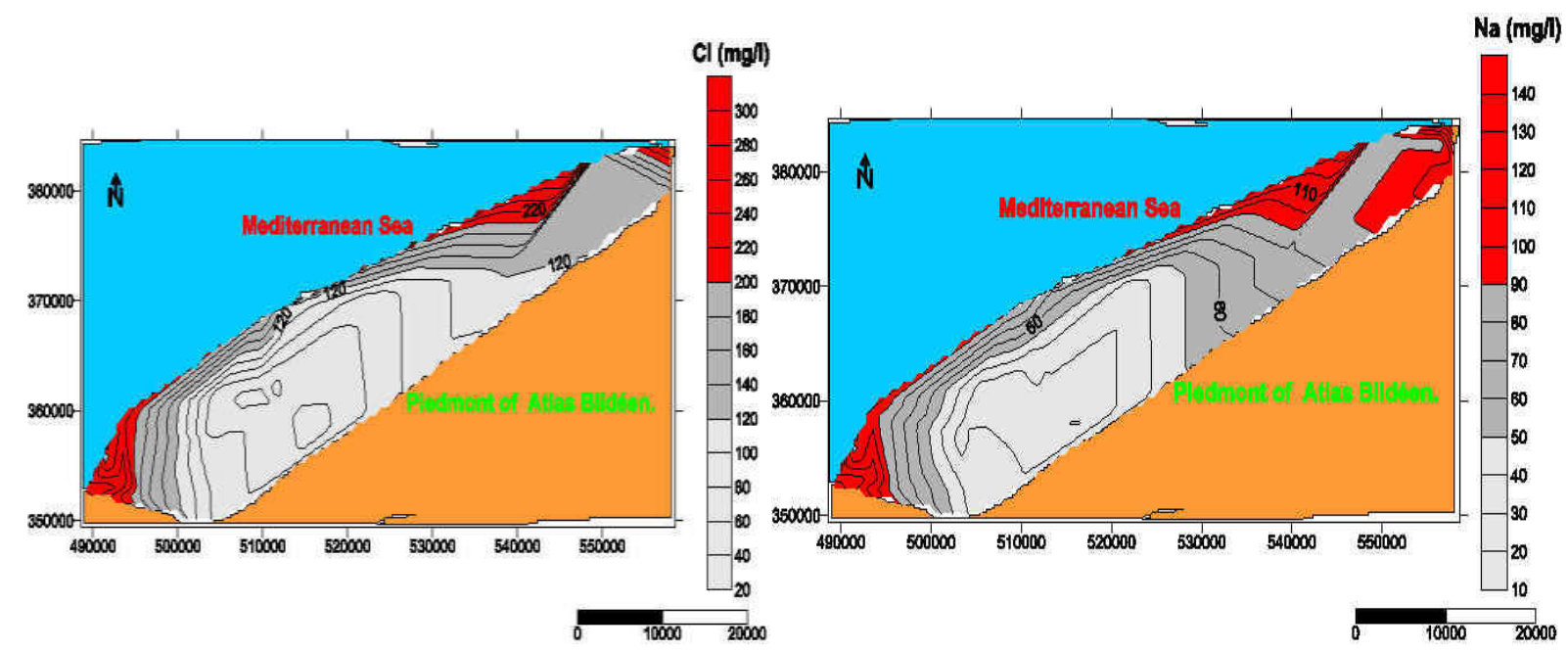

Fig.4e. Spatial distributions of Chloride

Fig.4f. Spatial distributions of Sodium 


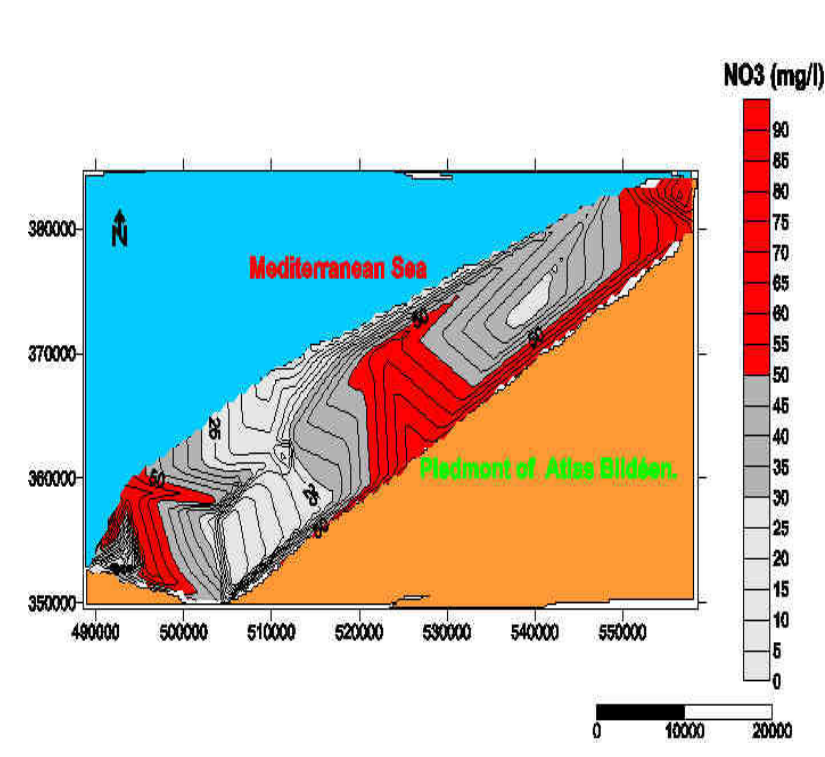

Fig.4g.Spatial distributions of Nitrate

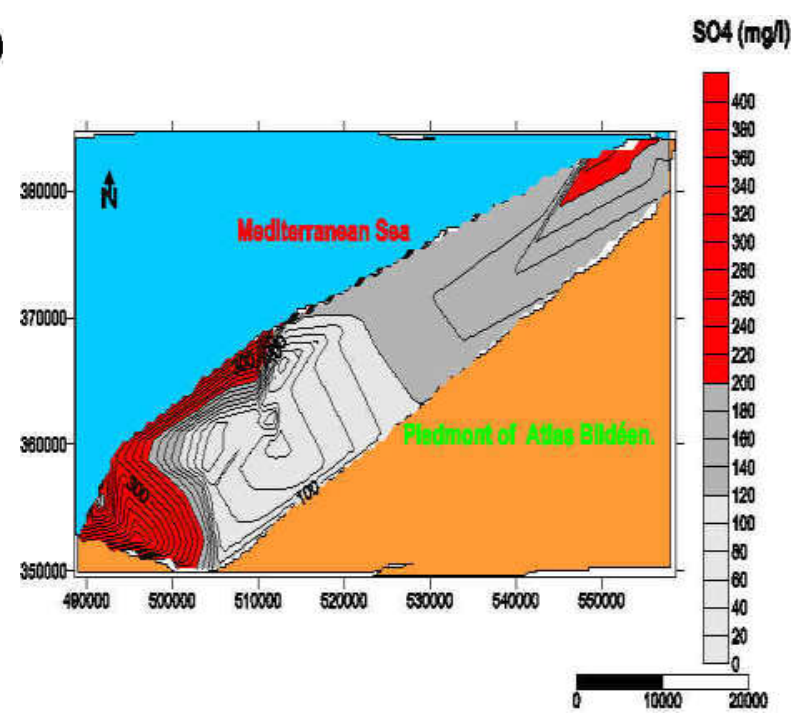

Fig.4h. Spatial distributions of Sulfate

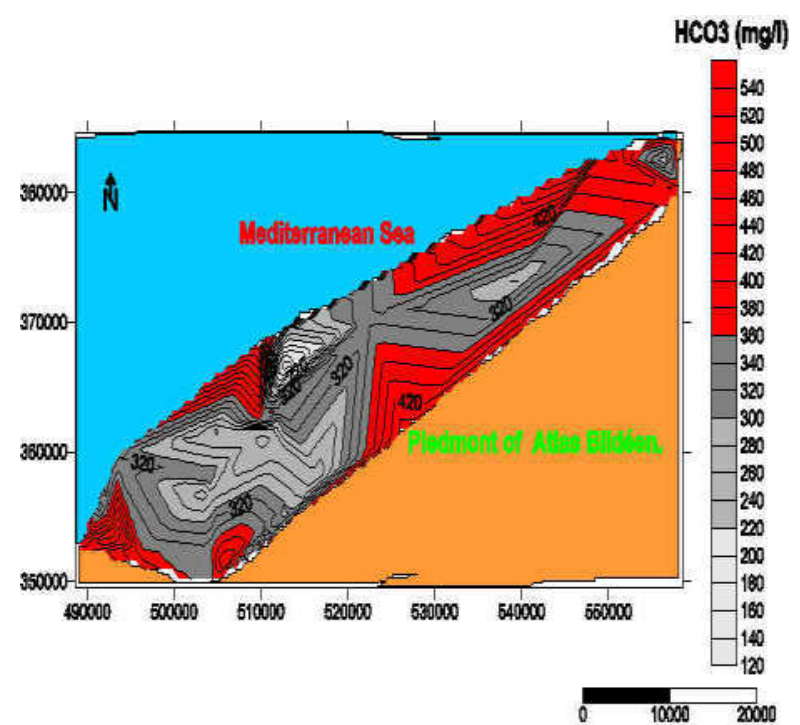

Fig.4j. Spatial distributions of Bicarbonate
Fig.4i. Spatial distributions of WQI

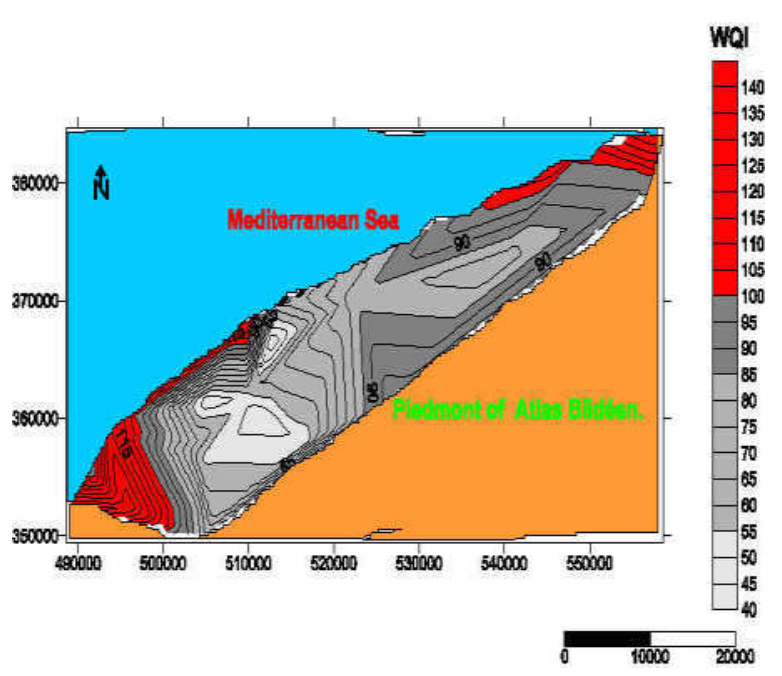

Spatial distribution map of Calcium (Fig.4d), Magnesium (Fig.4c), Sodium (Fig.4f), Chlorides (Fig.4e), Bicarbonates (Fig.4j), and in EC (Fig.4a), show that the zones with strong concentrations are observed in North East of the plain. The high salinization in the eastern Mitidja has been attributed to seawater intrusion process, because of increasing contents of chloride ions and sodium value distribution [1, 4]. According to Ait Ouali [1], The demographic development has which generates a demand for increasingly important water as well as the effects of the dryness of these two decades associated with geographical factors related to the coastal localization and the weak slope of the aquifer, naturally favorited this phenomenon, especially in this part, What caused the disturbance of the interface fresh 
water/saline water. The extreme West of the aquifer also presents high concentrations in EC (Fig.4a), TDS (Fig.4b), Chloride (Fig.4e), Sodium (Fig.4f), and Sulphate (Fig.4h). This will be explained by the dissolution of the eruptive and the evaporitic formations [4]. Based on the geological and geographical data, the domestic and industrial wastewater were included like source of the concentrations raised in this sector. The presence of Bicarbonates (Fig. $4 \mathrm{j}$ ) in water is due to the dissolution of the carbonated formations which border the plain. The strongest nitrate values (Fig.4g) are recorded in the center and west of the plain where the use of fertilizers in agriculture is intense. A local contamination by the septic tanks and systems sewerages could be also responsible. The geology of Mitidja in the shape of basin associated with an aquifer made up with permeable formations (gravels and sands), supported the immigration of the nitrate towards the saturated zone and the contamination of the groundwater. The spatial distribution map of the WQI (Fig. 4i) shows that the western and eastern of the study area have poor groundwater quality. In general, WQI decreases from the center to the perepherie of the Mitidja aquifer, under the effects of the direction of groundwater flow (Fig.3).

\subsection{Application of statistical analysis}

Cluster analysis and factor analysis of the groundwater quality in the study area was studied.

\subsubsection{Hierarchical Cluster Analysis (HCA)}

The cluster analysis classified the groundwater samples of Mitidja plain into two clusters based on the similarities among the chemical parameters involved in the groundwater quality (Fig.5b). The output of the Q-mode cluster analysis is given as a dendrogram (Fig.5a). Two clusters are selected based on visual examination of the dendogram, each representing a hydrochemicalfacies (Fig.7a-7b-7c-7d). Cluster 1, representing $60 \%$ of all samples, are characterized by relatively low salinity (mean $\mathrm{EC}=1038.72 \mu \mathrm{S} / \mathrm{cm})(\mathrm{Tab} .4)$ and abundance orders (mg/l) $\mathrm{Ca}^{2+}>\mathrm{Na}^{+}>\mathrm{Mg}^{2+}>\mathrm{K}^{+}$and $\mathrm{HCO}_{3}>\mathrm{SO}_{4}{ }^{2-}>\mathrm{Cl}^{-}>\mathrm{NO}_{3}{ }^{-}$(Fig.7a). These waters are classified as Bicarbonated calcic water type. 


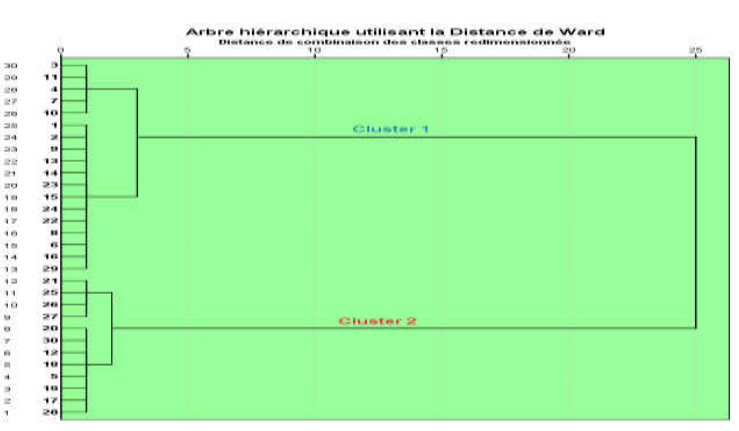

Fig.5a. Q-mode Hierarchical Cluster Analysis

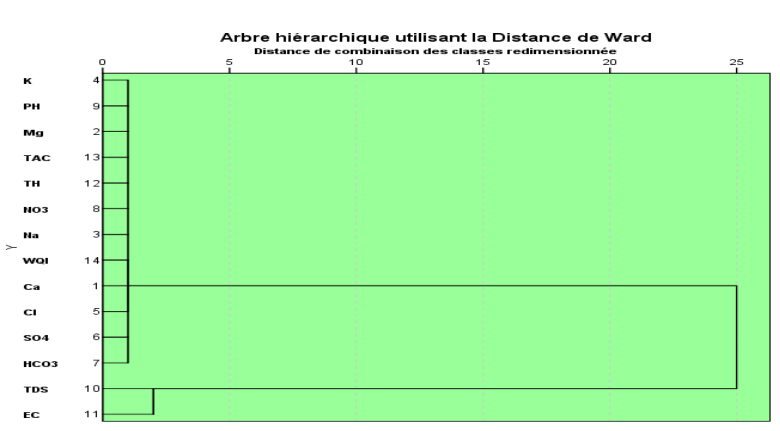

Fig.5b. R-mode Hierarchical Cluster Analysis

Cluster 2 is made up of water samples wherein the cation composition was dominated by $\mathrm{Ca}^{2+}$ and $\mathrm{Na}^{+}$, with anion composition varying from dominantly $\mathrm{HCO}_{3}{ }^{-}$to dominantly $\mathrm{SO}_{4}{ }^{2-}$ plus $\mathrm{Cl}^{-}$(Fig.7b). EC values (mean=2124. $83 \mu \mathrm{S} / \mathrm{cm}$ ) are significantly greater than those of cluster 1 , reflecting a more effective weathering process. The most pronounced characteristic of this group is the increase in the $\mathrm{Cl}^{-}, \mathrm{NO}_{3}{ }^{-}$and $\mathrm{SO}_{4}{ }^{2-}$ content (Tab.4), Knowing that $40 \%$ of the samples belong to this cluster.

Table4. Mean parameter values of the two principal water groups

\begin{tabular}{|c|c|c|c|c|c|c|}
\hline \multirow{2}{*}{ paramètres } & \multicolumn{3}{|c|}{ Cluster 1 (n=18) } & \multicolumn{3}{c|}{ Cluster 2 (n=12) } \\
\cline { 2 - 7 } & Min & Max & Moy & Min & Max & Moy \\
\hline $\mathrm{PH}$ & 7.10 & 8.30 & 7.72 & 7.20 & 8.00 & 7.61 \\
\hline $\mathrm{CE}$ & 520 & 1575 & 1038.72 & 1763 & 2600 & $\mathbf{2 1 2 4 . 8 3}$ \\
\hline $\mathrm{Ca}^{2+}$ & 22 & 190 & 109.61 & 155 & 254 & $\mathbf{1 9 4 . 5 0}$ \\
\hline $\mathrm{Mg}^{2+}$ & 2 & 35 & 20.33 & 13 & 73 & 50.91 \\
\hline $\mathrm{Na}^{+}$ & 19 & 79 & 37.28 & 81 & 148 & 107.08 \\
\hline $\mathrm{K}^{+}$ & 2 & 7 & 2.67 & 2 & 8 & 3.25 \\
\hline $\mathrm{Cl}^{-}$ & 32 & 124 & 67.22 & 122 & 312 & 216.91 \\
\hline $\mathrm{SO}_{4}^{2-}$ & 2 & 197 & 93.89 & 122 & 424 & $\mathbf{2 5 9 . 9 1}$ \\
\hline $\mathrm{HCO}_{3}^{-}$ & 107 & 458 & 297.50 & 275 & 549 & 405.58 \\
\hline $\mathrm{NO}_{3}^{-}$ & 2 & 76 & 28.44 & 5 & 93 & $\mathbf{5 3 . 5 0}$ \\
\hline $\mathrm{TH}^{-}$ & 9 & 62 & 35.83 & 44 & 94 & 70.00 \\
\hline
\end{tabular}

The diagram of Piper, Sholler-Berakallof, Stabler and Stiff (Fig.7a-7d) shows the prevalence of the calcic and magnesian bicarbonate facies for Cluster 1. This type of facies characterizes the zones of recharge of water and draws its origin of the carbonated formations bordering the aquifer.The cluster 2 has a chlorinated and sulphated calcic and magnesian chemical signature.According to Belaidi and Salhi [2], the prevalence of this type offacies is due to the 
nature of the geological reservoir. According to these same authors, the chlorinated calcic facies is important in the quaternary aquifer of Mitidja and is spread especially in the center the aquifer. This can be explained by the presence of the alluvial formations salted of Mio-Plio Quaternary and the presence of the evaporates.According to these results, we note that the water of the aquifer of Mitidja derives from a bicarbonated calcic facies and evolves to the chlorinated calcic one. One can suspecter in this case or an intrusion of marine water, or the presence of évaporite (halite). According to Banton and Bangoy [22], if this evolution is accompanied by a mineralization, one can think that this water would come from precipitations and would circulate in a calcareous environment in which it acquires its facies. This obliged us to use the diagram of Gibbs to identify the origin and the mechanisms of acquisitions of the mineralization of the aquifer of Mitidja. In this study, we used Gibbs plots of TDS versus the ion ratios $\mathrm{Na}^{+} /\left(\mathrm{Na}^{+}+\mathrm{Ca}^{2+}\right)$ and $\mathrm{Cl}^{-} /\left(\mathrm{Cl}^{-}+\mathrm{HCO}_{3}^{-}\right)$, the results are presented in figure 6 .

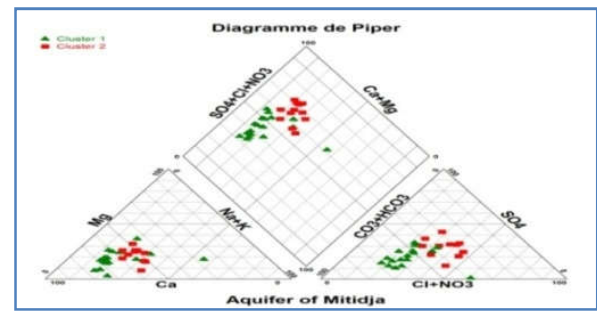

Fig.7a. Piper plot

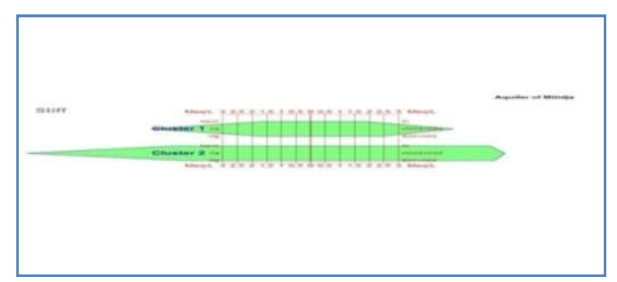

Fig.7c. Stiff diagram

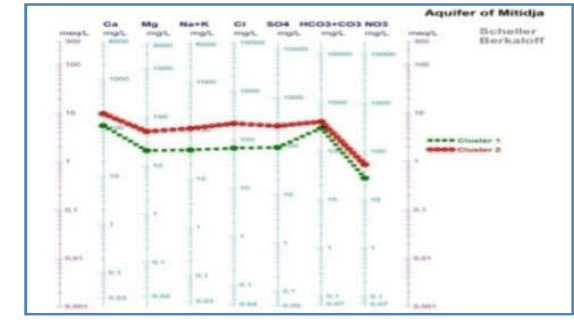

Fig.7b.Scholler-berkallof diagram

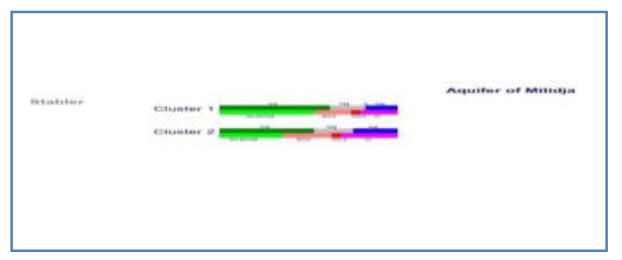

Fig.7d. Stabler diagram

From Fig.6 the cluster 1 falls on the rock dominance and that of cluster 2 on the evaporation/precipitation dominance. These patterns indicate that rock weathering was the dominant mechanism controlling the hydrogeochemistry in the study area [23]. 

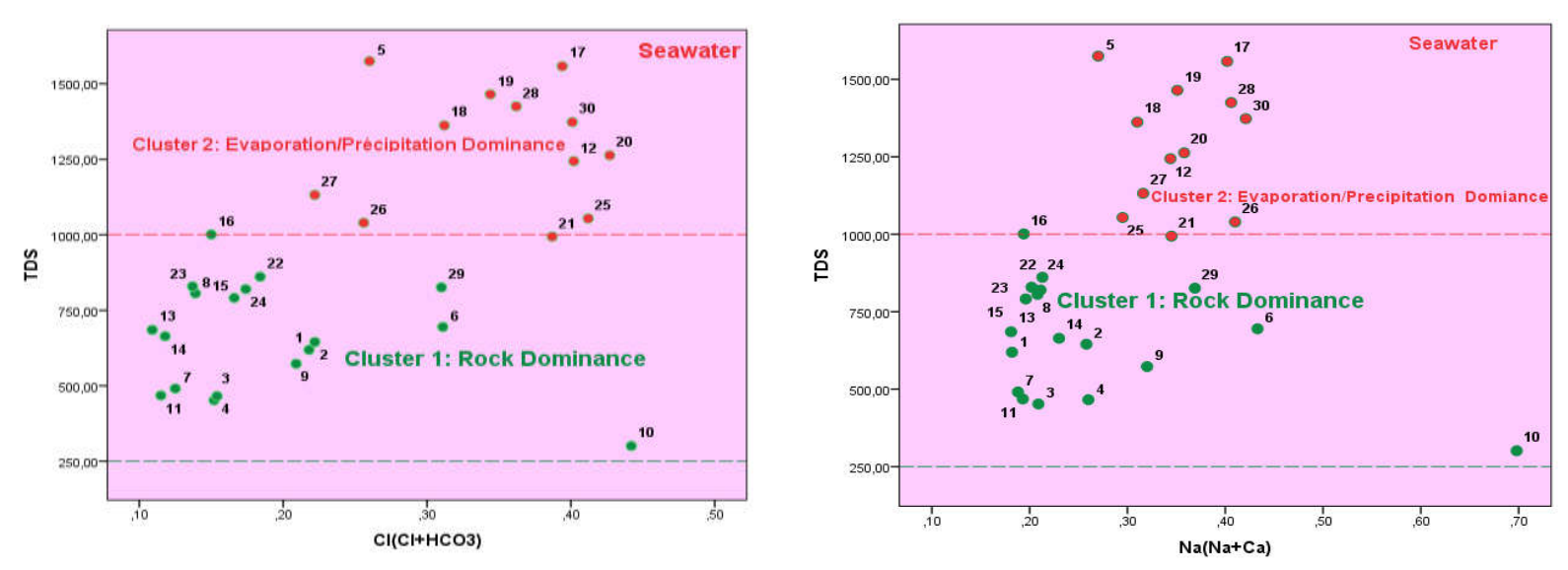

Fig.6. Gibbs' diagram

\subsubsection{Principal Component Analysis (ACP)}

The criterion of Kaiser [24] was applied in order to determine the full number of significant factors influencing quality of the aquifer system.According to this criterion, only the factors having an eigenvalue higher or equal to 1 will be accepted like possible sources of variance in the data. Factor analysis was performed for each cluster.

\section{Cluster 1}

Three principal components (PC) were extracted. The results of Table 5 show that the three PC account for more than $82.06 \%$ of the total variance. PC1 represents about $43.24 \%$ of the variance and has high absolute loadings for $\mathrm{HCO}_{3}{ }^{-}, \mathrm{TAC}, \mathrm{Ca}^{2+}$, THand WQI, what explains the process of the dissolution of the bicarbonate calcic formations (dolomite)in the study area. PC 2, which accounts for $26.64 \%$ of the total variance contains high loadings for $\mathrm{Na}^{+}, \mathrm{Cl}^{+}$and EC. This factor expresses the dissolution of halite $(\mathrm{NaCl}) . \mathrm{PC} 1$ and $\mathrm{PC} 2$ represents the major geochemical processes taking place, which is most probably the presence and dissolution of some carbonate, dolomitic and evaporates minerals in the aquifer. PC3 explain $12.17 \%$ of the variation and show high loadings for $\mathrm{pH}$.

\section{Cluster 2}

Three significant PCs are supposed to be indicative of the natural and anthropogenic processes. PC1, PC2 and PC3 explain $86.78 \%$ of the total variationin the hydrochemistry of the aquifer of Mitidja. Most of the variance is contained in the PC1 (34.21\%), which is associated with the variables $\mathrm{Mg}^{2+}, \mathrm{SO}_{4}{ }^{2-}$ and WQI (Table 5). This factor relates the dissolution of the gypseous levels were contained in the aquifer. PC 2 represents $26.95 \%$ of 
the total variation in the hydrochemistry and has high loadings for $\mathrm{Cl}^{-}, \mathrm{Na}^{+}$and $\mathrm{EC}$, what expresses the dissolution of halite $(\mathrm{NaCl})$. The variables $\mathrm{HCO}_{3}{ }^{-}$and $\mathrm{NO}_{3}{ }^{-}$contribute most strongly to the third component (PC3) that explains $25.61 \%$ of the total variance. PC3 represent the factor of pollution of the aquifer of Mitidja by nitrates. This pollution is correlated negatively with the other variables, which indicates an exogenic origin of the nitrates (anthropogenic origin), had with the use of the nitrate fertilizers in excess in agriculture.

Table 5.Varimax rotation PCA loading matrix

\begin{tabular}{|c|c|c|c|c|c|c|}
\hline & \multicolumn{3}{|c|}{ Cluster $1(n=18)$} & \multicolumn{3}{|c|}{ Cluster $2(n=12)$} \\
\hline & 1 & 2 & 3 & 1 & 2 & 3 \\
\hline $\mathrm{Ca}^{2+}$ & 0.925 & 0.179 & 0.270 & 0.581 & 0.369 & 0.573 \\
\hline $\mathrm{Mg}^{2+}$ & 0.498 & 0.680 & 0.145 & 0.911 & 0.053 & 0.094 \\
\hline $\mathrm{Na}^{+}$ & -0.042 & 0.906 & -0.092 & -0.082 & 0.863 & 0.260 \\
\hline $\mathbf{K}^{+}$ & -0.178 & -0.186 & -0.361 & -0.130 & 0.693 & 0.296 \\
\hline $\mathrm{Cl}^{-}$ & -0.001 & 0.984 & 0.019 & 0.205 & 0.948 & 0.065 \\
\hline $\mathrm{SO}_{4}{ }^{2+}$ & 0.418 & 0.611 & 0.499 & 0.934 & -0.178 & 0.159 \\
\hline $\mathrm{HCO}_{3}^{-}$ & 0.929 & -0.002 & 0.161 & 0.121 & 0.316 & 0.933 \\
\hline $\mathrm{NO}_{3}^{-}$ & 0.735 & -0.106 & -0.400 & -0.471 & -0.137 & -0.787 \\
\hline PH & -0.012 & 0.164 & -0.873 & 0.692 & -0.323 & 0.497 \\
\hline EC & 0.687 & 0.658 & 0.250 & 0.465 & 0.820 & 0.256 \\
\hline TH & 0.883 & 0.376 & 0.257 & 0.851 & 0.225 & 0.369 \\
\hline TAC & 0.934 & 0.006 & 0.155 & 0.119 & 0.319 & 0.932 \\
\hline WQI & 0.885 & 0.402 & 0.038 & 0.819 & 0.403 & 0.020 \\
\hline Eigen value & 5.62 & 3.46 & 1.58 & 4.44 & 3.5 & 3.33 \\
\hline$\%$ of variance & 43.24 & 26.64 & 12.17 & 34.21 & 26.95 & 25.61 \\
\hline Cumulative \% & 43.24 & 69.88 & 82.06 & 34.21 & 61.16 & 86.78 \\
\hline
\end{tabular}

\subsection{Application of the Water Quality Index (WQI)}

To estimate the impact of each chemical parameter on the quality of the aquifer of Mitidja, the effective weight was calculated. The results were presented in Table 6. TDS, $\mathrm{pH}$ and $\mathrm{Ca}^{2+}$ 
parameters have the highest mean effective weights value with $25.84 \%, 14.55 \%$ and 13.48 $\%$, respectively. These results indicate that the salinity, translated by the TDS, is the principal factor which degrades the chemical quality of the aquifer of Mitidja. However, magnesium (7.64\%) and nitrate $(15.06 \%)$ have also a considerable impact on the chemical quality of water (Tab.6). The study of the correlations between the Water Quality Index and the other parameters (Fig.8 a-j), Confirm this observation, and reveal the major contribution of the natural processes in the deterioration of the quality of the aquifer of Mitidja in particular dissolution of calcic and magnesian carbonated formations.

Table 6.Statistical analysis of the effective weight

\begin{tabular}{|ccccccc|}
\hline Parameters & Weight & Relative & \multicolumn{4}{c|}{ Effective weight } \\
\cline { 3 - 7 } & & weight $(\mathbf{W i})$ & Min & Max & Mean & Mean \% \\
$\mathbf{P H}$ & $\mathbf{4}$ & $\mathbf{1 2 . 1}$ & 11.45 & 14.45 & $\mathbf{1 2 . 3 9}$ & $\mathbf{1 4 . 5 5}$ \\
$\mathbf{C a}^{2+}$ & $\mathbf{2}$ & $\mathbf{6}$ & 0.18 & 1.88 & 0.99 & 1.16 \\
$\mathbf{M g}^{2+}$ & $\mathbf{2}$ & $\mathbf{6}$ & 1.76 & 20.32 & 11.48 & $\mathbf{1 3 . 4 8}$ \\
$\mathbf{N a}^{+}$ & $\mathbf{2}$ & $\mathbf{6}$ & 0.4 & 14.6 & 6.51 & 7.64 \\
$\mathbf{K}^{+}$ & $\mathbf{2}$ & $\mathbf{6}$ & 0.57 & 4.44 & 1.95 & 2.29 \\
$\mathbf{T A C}^{+}$ & $\mathbf{3}$ & $\mathbf{9}$ & 1 & 4 & 1.45 & 1.70 \\
$\mathbf{T D S}^{+}$ & $\mathbf{4}$ & $\mathbf{1 2 . 1}$ & 7.28 & 38.11 & $\mathbf{2 2}$ & $\mathbf{2 5 . 8 4}$ \\
$\mathbf{C l}^{-}$ & $\mathbf{3}$ & $\mathbf{9}$ & 1.15 & 11.23 & 4.57 & 5.37 \\
$\mathbf{N O}_{\mathbf{3}}{ }^{-}$ & $\mathbf{5}$ & $\mathbf{1 5}$ & 0.66 & 31 & $\mathbf{1 2 . 8 2}$ & $\mathbf{1 5 . 0 6}$ \\
$\mathbf{S O}_{\mathbf{4}}{ }^{2-}$ & $\mathbf{4}$ & $\mathbf{1 2 . 1}$ & 0.12 & 25.65 & 9.69 & 11.38 \\
\hline
\end{tabular}




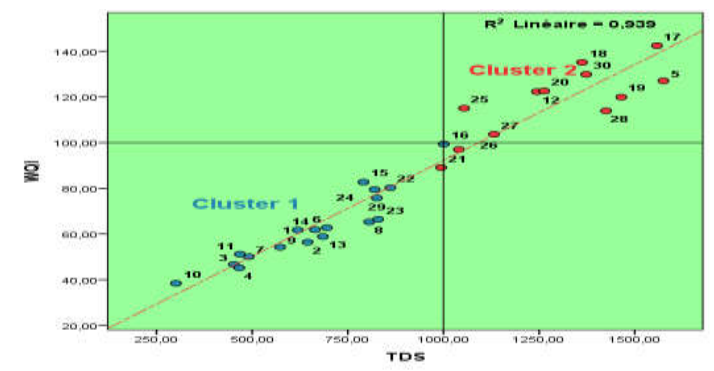

Fig.8a. Correlation between WQI and TDS

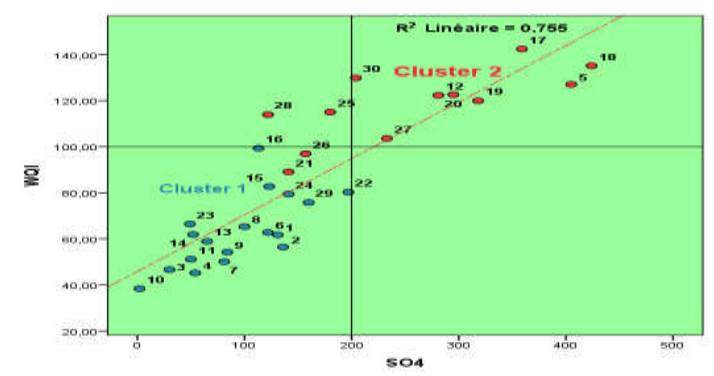

Fig.8c. Correlation between WQI and $\mathrm{SO}_{4}{ }^{2-}$

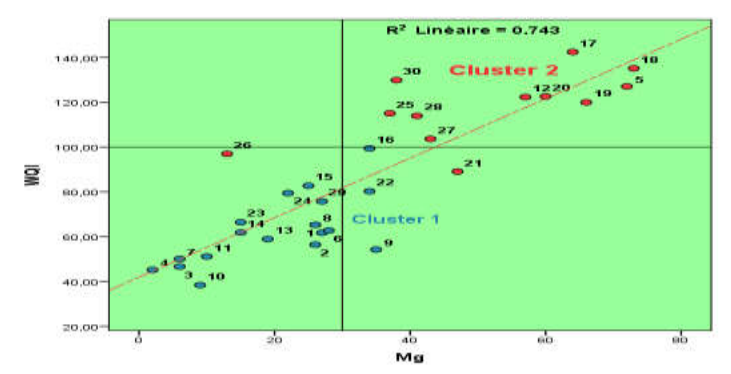

Fig.8e. Correlation between WQI and $\mathrm{Mg}^{2+}$

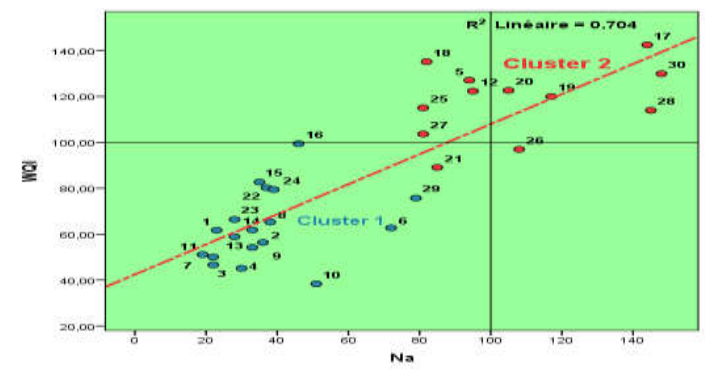

Fig.8g. Correlation between WQI and $\mathrm{Na}^{+}$

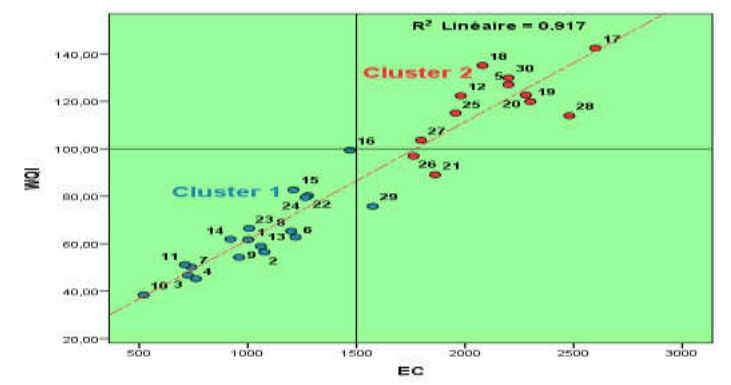

Fig.8i. Correlation between WQI and EC

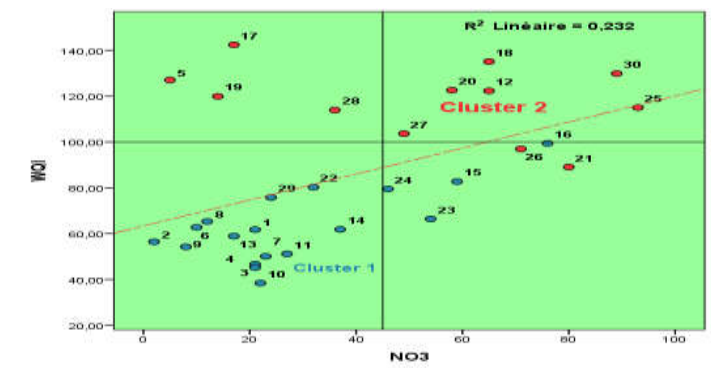

Fig.8b. Correlation between WQI and $\mathrm{NO}_{3}{ }^{-}$

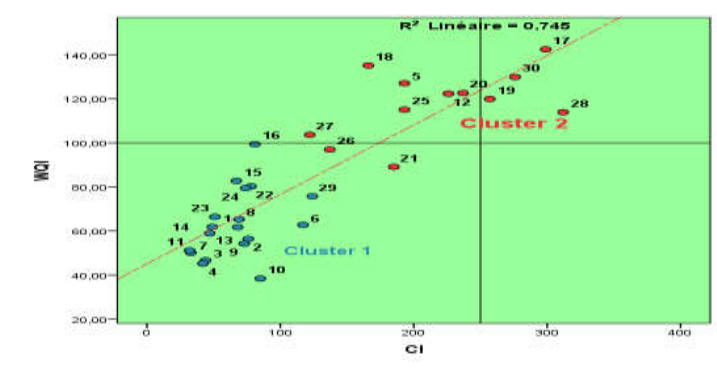

Fig.8d.Correlation between WQI and $\mathrm{Cl}^{-}$

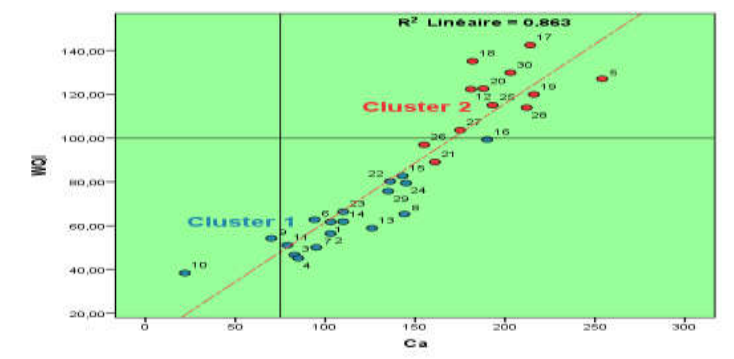

Fig.8f. Correlation between WQI and $\mathrm{Ca}^{2+}$

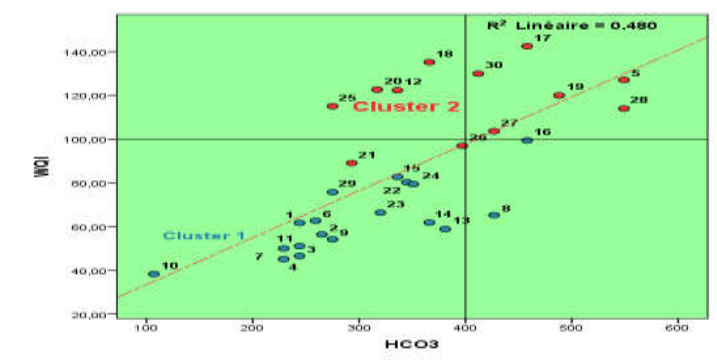

Fig.8h. Correlation between WQI and $\mathrm{HCO}_{3}{ }^{-}$

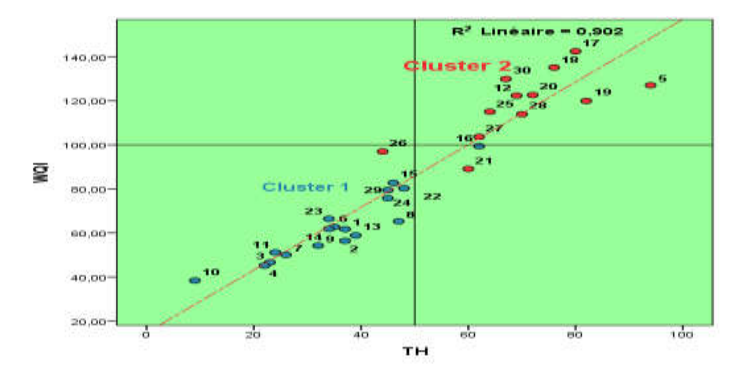

Fig.8j. Correlation between WQI and TH 


\section{CONCLUSION}

A result of analytical data reveals that the abundance of the major ions is as follows: $\mathrm{Ca}^{2+} \geq \mathrm{Na}^{+} \geq \mathrm{Mg}^{2+} \geq \mathrm{K}^{+}$and $\mathrm{HCO}_{3}{ }^{-} \geq \mathrm{SO}_{4}{ }^{2-} \geq \mathrm{Cl}^{-} \geq \mathrm{NO}_{3}{ }^{-}$. The groundwater of Mitidja plain evolves from less saline water to brackish water along the topographic flow path. Overall, these waters can be classified as recharge area waters (Cluster 1), transition area waters and discharge area waters (Cluster2). There are two major mechanisms that regulate the chemistry of the groundwater: Evaporation Dominance and Rock Dominance. The interpretation of the geochemical data reveals frequent participation of seawater in the Eastern areas water samples, showing a very high salinity waters. Also, we conclude that salinization in the western of Mitidja plain has its origin in the dissolution of gypsum, dolomite and halite, as well as contamination by nitrate caused mainly by extensive agricultural activity. The effects of water quality parameters on the WQI show that the highest mean effective weight value belong to the $\mathrm{NO}_{3}{ }^{-}$and $\mathrm{SO}_{4}{ }^{2-}$ parameters compared with the other parameters. This study demonstrates that the use of WQI methods and statistical analysis combined with the GIS could provide Efficacy Tools for ground water quality assessment.

\section{REFERENCES}

[1]Ait-Ouali A, Synthèse hydrogéologique et vulnérabilité à la pollution du système aquifère quaternaire de la Mitidja. Mémoire de magistère USTHB.2007.

[2]Belaidi M et Salhi M, Note sur la piezometrie de la nappe de la Mitidja (campagne2010). Agence nationale des ressources hydrauliques. 2011. 7 p.

[3]Yahiaoui S, Evaluation de la qualité des eaux souterraines de la Mitidja et leur aptitude à l'irrigation. Mémoire de magister. Génie de l'eau. ENSH.2011.

[4]Djoudar-Hallal D, Approche méthodologique de la vulnérabilité de la ressource en eau souterraine en milieu fortement urbanisé: exemple en Algérie des plaines littorals (Mitidja). Thèse de doctorat. USTHB.2014.

[5] Hadjoudj O, Bensemmane R, Saoud z et Reggabi M, Pollution des eaux souterraines de la mitidja par les nitrates : Etat des lieux et mesures correctives. Eur. j.waterqual, 2014. 45 ; 57-68 
[6] Hadjoudj - Benabdesslam O, Pollution des nappes aquifères de la Mitidja par les nitrates. Thèse de doctorat es Sciences en Hydrologie-Bromatologie. 2007

[7] Mimouni O, CheikhLounis G, Kabouche S, Menceur H, Vulnerability to pollution of Mitidja plain alluvial aquifer (Algiers-Algeria).International Journal of EnhancedResearch in Science Technology\& Engineering. 2015. 4: (137-143).

[8] Imache A, Le Goulven P, Bouarfa S, Chabaca M, Evolutions de la demande en eau agricole dans la plaine irriguée de la Mitidja, Algérie. Actes du troisième atelier régional SIRMA (Nabeul, Tunis), CD-Rom, Édit. CIRAD, Montpellier. 2007. 2 p.

[9] Glangeaud L, Étudegéologique de la région littorale de la province d'Alger. Bull Serv. Cartes Géol. Algérie.1932.

[10] Sekkal R, Hydrologie de la nappe de la Mitidja (Algérie) : étude hydrodynamique des champs captants de la ville d'Alger. UniversitéScientifiqueetMédicale de Grenoble, France.1986.

[11]Khouli M R, Djabri L, Impact Of Use Of Agricultural Inputs On The Quality Of Groundwater Case Of Mitidja Plain (Algeria). GeographiaTechnica, 2011, (2) 35- 44.

[12]Toubal A-C, Apport de la géophysique à l'étude des problèmes hydrodynamique et d'invasion marine en milieu souterrains. Exemple des plaines d'Annaba, de la Mitidja et de la baie d'Alger. Thèse de Doctorat d'état. USTHB,1989.

[13]Rodier J, Legube B, Merlet N, Brunet R. L'analyse de l'eau : eaux naturelles eaux résiduaires, eaux de mer. 8eme édition. Dunod.Paris, France. 2009.1579 p.

[14]WHO.Guidelines for drinking water quality V.1 Recommendations. Switzerland: Geneva (1983) pp. 130.

[15]Abbasi SA (2002) Water quality indices, state of the art report, National Institute of Hydrology, Scientific contribution no.INCOH/SAR-25/2002, INCOH, Roorkee, p 73

[16]Debels, P., Figueroa, R., Urrutia, R., Barra, R., Niell, X., 2005. Evaluation of water quality in the Chilla'n river (Central Chile) using physicochemical parameters and a modified water quality index.Environ.Monit.Assess. 110, 301-322.

[17]Tsegaye, T., Sheppard, D., Islam, K.R., Johnson, A., Tadesse,W., Atalay, A., Marzen, L., 2006. Development of chemical index as a measure of in stream water quality in response to 
land use and land cover changes.Water Air SoilPollut.174, 161-179.

[18]Saeedi, M., Abessi, O., Sharifi, F., Maraji, H., 2009. Development of groundwater quality index. Environ. Monit. Assess. 163 (1-4), 327-335.

[19]Yidana S.M, Yidana A. Assessing water quality using water quality index and multivariate analysis. Environmental Earth Sciences, 2010. 59, 1461-1473.

[20] Zghibi, A., Merzougui, A., Zouhri, L., Tarhouni, J., African Earth Sciences (2013), doi: http://dx.doi.org/10.1016/j.jafrearsci.2013.09.004

[21] Ketata, M., Gueddari, M. \&Bouhlila, R. Arab J Geosci (2012) 5: 1379.doi:10.1007/s12517-011-0292-9

[22]Banton O, Bangoy L-M, Hydrogeologie : Multiscience environnementale des eaux souterraines. Presses de l'universite du Quebec.1999.377 p.

[23]Gibbs R.J, Mechanism controlling world water chemistry.Sciences 1970. 170:795840 [24]Kaiser H.F, The application of electronic computers to factor analysis. Educational and Psychological Measurement, 1960.20, 141- 5.3

\section{How to cite this article:}

Zamiche S, Hamaidi-Chergui F, Demiai A, Belaidi M. Identification of factors controlling the quality of groundwater in Mitidja plain (North-Algeria) using indexing method and statistical analysis. J. Fundam. Appl. Sci., 2018, 10(1), 248-267. 